\title{
CYP3A5 Inhibitor
}

National Cancer Institute

\section{Source}

National Cancer Institute. CYP3A5 Inhibitor. NCI Thesaurus. Code C155914.

Any substance capable of decreasing the activity of cytochrome P450 3A5. 